http://jmscr.igmpublication.org/home/ ISSN (e)-2347-176x ISSN (p) 2455-0450 crossref DOI: https://dx.doi.org/10.18535/jmscr/v7i9.22

\title{
Comparative Analysis of Metered Dose Inhaler (MDI) and Dry Powder Inhaler (DPI) at Rural Bangladesh Perspective
}

\author{
Authors \\ Dr D S M Zakir Hossain ${ }^{*}$, Dr Md. Ali Hossain², Dr Md. Sakur Khan ${ }^{3}$ \\ ${ }^{1}$ Assistant Professor, Respiratory Medicine, Patuakhali Medical College, Patuakhali \\ ${ }^{2}$ Professor, Respiratory Medicine, National Institute of Diseases of the Chest and Hospital \\ ${ }^{3}$ Assistant Professor, Respiratory Medicine, National Asthma Center, Mohakhali, Dhaka \\ *Corresponding Author
}

Dr D S M Zakir Hossain

\begin{abstract}
Metered Door Inhaler and Dry powder inhaler are both used to treat the symptoms, such as: wheezing, coughs etc. of pulmonary disease in a Patient. The main objective of this study is to find out the comparative analysis of pMDI \& DPI in asthma medication at rural area of Bangladesh. A cross sectional study including survey and interview was completed at in the outpatients department (OPD) of Patuakhali 250 Bed Sadar Hospital, Patuakhali. The sample was 120 Asthma patients studied over a period of six months from January 2019 to July 2019. The measurements of FEV1 \& VC demonstrate airflow obstruction and following the administration of a bronchodilator, confirm the diagnosis when a 15\% (and $200 \mathrm{ml}$ ) improvement in FEV1 is noted. Subsequent follow-up were done by Peak Flow Meter. Medications were used as single maintenance \& reliever therapy using Budesonide (ICS) \& Formeterol (LABA). Devices that were used for the study are Pressurized Metered Dose Inhaler (pMDI) and Dry Powder inhaler (DPI) eg: Aerolizer. Proper inhalation techniques of the inhaler were demonstrated to the patients by the health care staffs from the hospital.

pMDI and DPI (Aerolozer) have no significant differences in compliance issue in patient's points of view in terms of rural Bangladesh perspective. DPIs are flow dependent and require minimal patient to device co-ordination. pMDI requires patient to device co-ordination.
\end{abstract}

Keywords: MDI, SMART, DPI, In-Check DIAL,

\section{Introduction}

Asthma is progressively regular in young men yet after pubescence increasingly basic in females. Poor control of asthma prompts days lost from school or work, medical clinic affirmation and unexpected passing in certain patients mirrors the financial effects. Aviation routes of asthmatics are exceptionally touchy to specific things, which don't trouble individuals without asthma. These things are called - triggers-when an asthmatic comes in contact to them, an asthma episode begins. The airways become swollen, produce a lot of mucus and are fixed up. The accurate etiology is as yet obscure. Hereditarily inclined newborn child, presentation to bronchiolitis firmly correspond the improvement of asthma in future. The aviation routes of the asthmatics are observed to be inflamed and hyper responsive, a few triggers 
instigate an asthma attack if the inflamed airways are presented to them. The pervasiveness of asthma expanded relentlessly. Present estimation proposes that 300 million individuals overall experience the ill effects of asthma and by 2025 extra 100 million assume to diagnose as asthma. ${ }^{[1]}$ Basic triggers of asthma are allergens (outdoor, indoor and food eg: dander or pieces, insects, molds, house dust parasites, hamburger, hilsha, prawn), irritants (eg: tobacco smoke: wood smoke: air pollutants) upper respiratory tract infection, exercise: certain drugs (B blocker, aspirin, NSAID). ${ }^{[2,3]}$ Among the inhaler devices accessible are pressurized metered dose inhaler (pMDI), dry powder inhaler (DPI) which incorporate aerolizer, diskus, handihaler, rotahaler and so forth ${ }^{[4,5,6]}$

\section{Objective of the study}

\section{Main}

The core objective of the study is to make a comparative analysis between pMDI \& DPI in asthma medication at rural area of Bangladesh.

\section{Specific}

- To identify the effectiveness of the pMDI inhaler

- To identify the effectiveness of the DPI inhaler

- To identify the variation in the results or impacts

\section{Methods}

A cross sectional study was completed at the in the outpatients department (OPD) of Patuakhali 250 Bed Sadar Hospital, Patuakhali. A mixed method was applied for the study. A survey and interview was done on 120 Asthma patients over a period of six months from January 2019 to July 2019.

\section{Inclusion Criteria}

Most of the cases the basic selection criteria of Astma patients as sample were,

- either DPI user or MDI user,

- were diagnosed as Asthma patients by typical symptoms, and

- the patients had the ability to consent

\section{Results}

The table 1 shows the age distribution of the studied samples and table 2 shows the gender distribution of said samples or patients.

Table 1: Age group of the Asthma patient

\begin{tabular}{|l|c|c|c|}
\hline $\begin{array}{l}\text { Age } \\
\text { group }\end{array}$ & Percent & $\begin{array}{c}\text { Valid } \\
\text { Percent }\end{array}$ & $\begin{array}{c}\text { Cumulative } \\
\text { Percent }\end{array}$ \\
\hline $20-44$ & 52.0 & 52.0 & 51.0 \\
\hline $45-69$ & 48.0 & 48.0 & 100.0 \\
\hline Total & 100.0 & 100.0 & \\
\hline
\end{tabular}

Table 2: Gender of the Asthma patient

\begin{tabular}{|l|c|c|c|}
\hline Gender & Percent & $\begin{array}{c}\text { Valid } \\
\text { Percent }\end{array}$ & $\begin{array}{c}\text { Cumulative } \\
\text { Percent }\end{array}$ \\
\hline Male & 79.0 & 79.0 & 79.0 \\
\hline Female & 21.0 & 21.0 & 100.0 \\
\hline Total & 100.0 & 100.0 & \\
\hline
\end{tabular}

The asthma problem for the 120 samples at the starting point of the problem is detailed in the table 3 below:

Table 3: Asthma Problem Starting by Age Group

\begin{tabular}{|c|c|c|c|c|c|}
\hline \multirow{3}{*}{$\begin{array}{l}\text { Asthma pr } \\
\text { period in ag }\end{array}$} & \multirow[b]{2}{*}{$\begin{array}{l}\text { startin } \\
\text { ctive }\end{array}$} & & \multicolumn{2}{|c|}{ Types of inhaler used } & \multirow{3}{*}{ Total } \\
\hline & & & \multirow{2}{*}{$\begin{array}{l}\text { inhaler } \\
\text { (MDI) }\end{array}$} & \multirow{2}{*}{$\begin{array}{l}\text { Dry pow der } \\
\text { inhaler (DPI) }\end{array}$} & \\
\hline & \multirow{3}{*}{ Age } & & & & \\
\hline \multirow{3}{*}{5 to 15 years } & & $20-44$ & 2 & 7 & 9 \\
\hline & & $45-69$ & 7 & 0 & 7 \\
\hline & \multicolumn{2}{|l|}{ Total } & 8 & 6 & 14 \\
\hline \multirow[t]{3}{*}{16 to 35 years } & \multirow[t]{2}{*}{ Age } & |20-44 & 2 & 12 & 14 \\
\hline & & $45-69$ & $\begin{array}{l}1 \\
4\end{array}$ & 1 & 15 \\
\hline & \multicolumn{2}{|l|}{ Total } & $\mid \begin{array}{l}1 \\
6\end{array}$ & 13 & 29 \\
\hline \multirow[t]{3}{*}{36 to 50 years } & \multirow[t]{2}{*}{ Age } & $20-44$ & 0 & 23 & 23 \\
\hline & & $45-69$ & $\int_{0}^{1}$ & 0 & 10 \\
\hline & \multicolumn{2}{|l|}{ Total } & $0_{0}^{1}$ & 22 & 32 \\
\hline \multirow[t]{3}{*}{51 to 70 years } & \multirow[t]{2}{*}{ Age } & 20-44 & 0 & 1 & 1 \\
\hline & & $45-69$ & 9 & 0 & 9 \\
\hline & \multicolumn{2}{|l|}{ Total } & 9 & 1 & 10 \\
\hline
\end{tabular}


Figure 1 shows the asthma patients perception towards the cooperation and helpfulness of the healthcare staff with both medication administrations. Proper inhalation techniques were demonstrated to the patients by health care staffs. DPI is peak inspiratory flow rate (PIFR) dependent, usually $60 \mathrm{~L} / \mathrm{min}$ or higher, on the other hand MDI require a slow \& deep inhalation with PIFR less than $60 \mathrm{~L} / \mathrm{min}$. MDI require patientdevice co-ordination. The Perception of the patients regarding the afore-mentioned are described in figure 2 and 3.

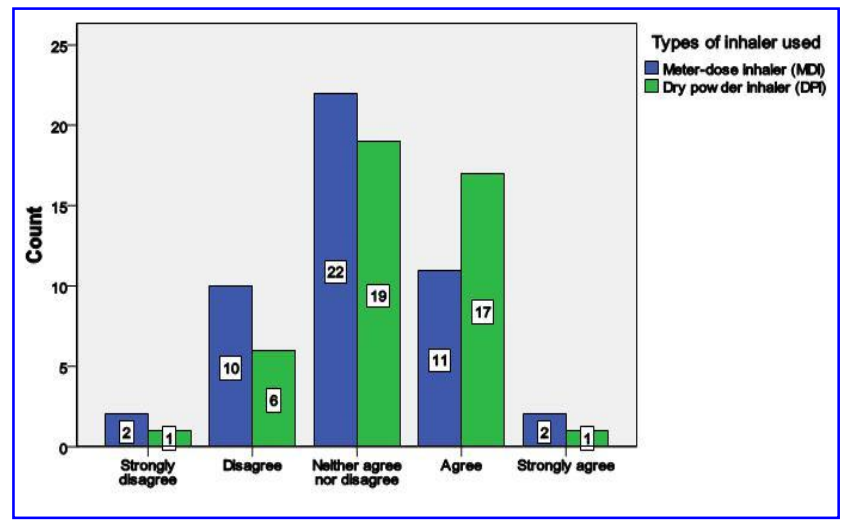

Figure 1: Cooperation of the healthcare staff in samples' perspectives

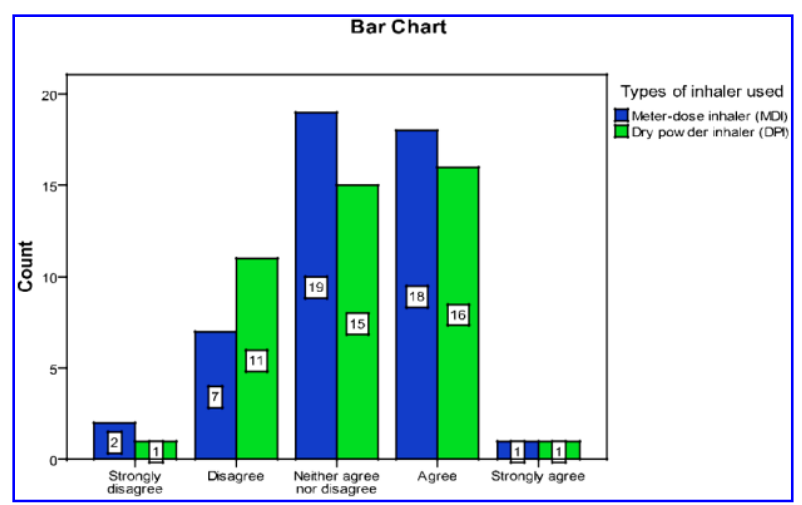

Figure 2: Ease of Patient-Device Coordination

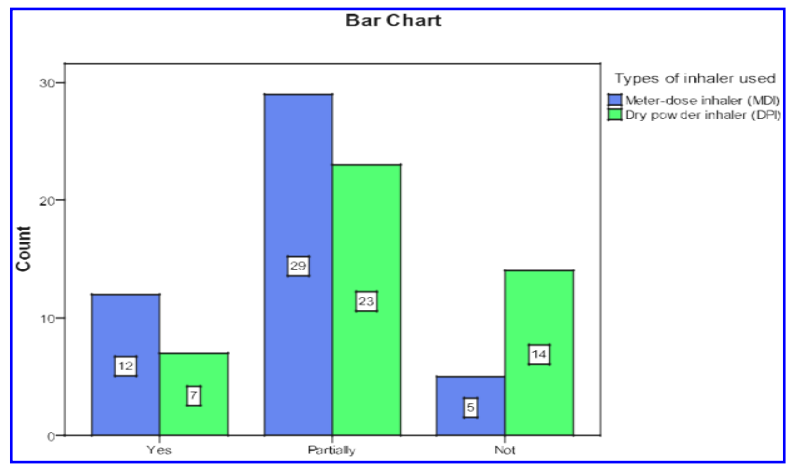

Figure 3: Types or Combination of Inhaler Used
Table: 4: ANOVA with Factor DPI and MDI

\begin{tabular}{|c|c|c|c|c|c|}
\hline Description & $\begin{array}{l}\text { Sum of } \\
\text { Squares }\end{array}$ & Df & $\begin{array}{l}\text { Mean } \\
\text { Square }\end{array}$ & $\mathbf{F}$ & Sig. \\
\hline \begin{tabular}{lc|} 
Good know-how & about \\
medication: & Between Groups \\
& Within Groups \\
& Total
\end{tabular} & $\begin{array}{c}.086 \\
87.585 \\
87.671\end{array}$ & $\begin{array}{c}1 \\
89 \\
90\end{array}$ & $\begin{array}{l}.086 \\
.983\end{array}$ & .087 & .769 \\
\hline $\begin{array}{l}\text { The medication is convenient to } \\
\text { use: } \\
\begin{array}{ll}\text { Between Groups } \\
\text { Within Groups } \\
\text { Total }\end{array}\end{array}$ & $\begin{array}{c}.155 \\
39.031 \\
39.187\end{array}$ & $\begin{array}{c}1 \\
89 \\
90\end{array}$ & $\begin{array}{l}.155 \\
.439\end{array}$ & .354 & .552 \\
\hline $\begin{array}{l}\text { That the staff listen and take the } \\
\text { Between Groups } \\
\text { patients view about asthma into Within Groups } \\
\text { Account }\end{array}$ & $\begin{array}{c}.542 \\
50.080 \\
50.621\end{array}$ & $\begin{array}{l}1 \\
88 \\
89\end{array}$ & $\begin{array}{l}.542 \\
.561\end{array}$ & .953 & .332 \\
\hline $\begin{array}{l}\text { That diseases is actively followed up Between } \\
\text { Groups: } \\
\qquad \text { Within Groups } \\
\text { Total }\end{array}$ & $\begin{array}{c}.751 \\
48.542 \\
49.297\end{array}$ & $\begin{array}{c}1 \\
89 \\
90\end{array}$ & $\begin{array}{l}.751 \\
.545\end{array}$ & 1.377 & .244 \\
\hline $\begin{array}{l}\text { health worker is } \\
\begin{array}{l}\text { That a care } \\
\text { responsible for the patient and Within Groups } \\
\text { his/her asthma: }\end{array} \\
\end{array}$ & $\begin{array}{r}1.189 \\
65.229 \\
66.418\end{array}$ & $\begin{array}{c}1 \\
89 \\
90\end{array}$ & $\begin{array}{c}1.189 \\
.733\end{array}$ & 1.621 & .205 \\
\hline \begin{tabular}{l}
\multicolumn{2}{l|}{ patient } \\
That the s received Between Groups \\
information and education about \\
the \\
diseases
\end{tabular} & $\begin{array}{l}.138 \\
69.708 \\
69.846\end{array}$ & $\begin{array}{l}1 \\
89 \\
90\end{array}$ & $\begin{array}{l}.138 \\
.783\end{array}$ & .175 & .676 \\
\hline
\end{tabular}

\section{Discussion}

Asthma is a chronic inflammatory disorder causing hyper-responsiveness of the airways to specific improvements bringing about intermittent variable airflow confinement, at any rate somewhat reversible exhibiting as wheezing, breathlessness, chest, tightness and coughing etc. The etiology is perplexing, and various ecological and hereditary determinants are ensnared. pressurized metered dose inhaler is the pharmacological specialist in a suspension plan that outcomes in a $10 \%$ respirable division; an agent in a weaken arrangement definition with an unstable propellant mix may result in up to $40 \%$ respirable fraction. The surfactant balances out the suspension by counteracting caking. ${ }^{[7,8,9,10]}$

A dry powder inhaler (DPI) is a breath-incited gadget that conveys the medication as particles contained in a capsule or blister that is punctured before use. This kind of inhaler requires a sufficient inspiratory stream for the organization of medications, since it does exclude a propellant. In view of this inspiratory stream prerequisite, DPIs are not suitable for the treatment of intense asthma attacks. For instance, the diskus is a low-resistance device and accordingly is reasonable for treatment 
of children and those with decreased lung function, though the turbuhaler is a high-opposition gadget that requires a higher inspiratory stream rate to aerosolize a comparable medication dose. ${ }^{[11,12,13,14]}$ Advantages of pMDIs are as its portability, lower risk of bacterial contamination, and multi-dose delivery capability. On the other hand the disadvantages of MDIs are: it needs correct actuation and inhalation coordination, the flammability possibility of new HFA propellants, and Oropharyngeal drug deposition. Additionally, DPI advantages are that it is breath-actuated, there is no need to hold breath after inhalation, spacer is not necessary, No need for propellant, and its portable. The disadvantages for DPI are that it needs $\square$ adequate inspiratory flow required for medication delivery, the

Humidity potentially causes powder clumping and reduced dispersal of fine particle mass, and it may result in high pharyngeal deposition ${ }^{[15,16,17,18]}$

From the ANOVA test result in SPSS, it can be seen that the $\mathrm{p}$ value is greater than the general alpha value .05 , which indicates that both pMDI and DPI (Aerolozer) have no significant differences in patient's perspective in rural Bangladesh. Dataset also shows that the pMDI is comparatively more convenient than DPI. Also, DPIs are flow dependent and thusly, require minimal patient-device co-ordination.

\section{Conclusion}

In conclusion of the study, it is seen that, pMDI and DPI essentially have no significant different in the perspective of the rural Bangladesh. However, a larger sample size is needed for better validity of the results. The research needs to be continued for a longer period of time to glean the effectiveness of the current asthma medication to create a better treatment plan for the disease.

\section{References}

1. Davisdson,s principles and Practice of medicine$23^{\text {rd }}$ edn: Respiratory medicine chapter -Chronic obstructive pulmonary disease: Asthma section.
2. Hassan MR, Hossain MA, Mahmud MA, Kabir ARM, Amin RM, et al. editors. National Guidelines Asthma Bronchiolitis COPD, Asthma Association, Bangladesh $3^{\text {rd }}$ ed. 2005. 19-133.

3. Global Burden of Asthma. Global Initiative for Asthma (GINA), 2004.

4. Managing Asthma in SMART Fashion: A Review: K H Jessy et all: Chest \& Heart Journal 2012; 36(1):81-87.ISSN 1562-5044.

5. National guideline:Asthma \& COPD;Asthma Association:Bangladesh; $5^{\text {th }}$ edn: Jan:2016 www.asthmabd.net.

6. Pittsburgh Regional Health Initiative and Center for Healthcare Quality and Payment Reform (C) 2008-2011

7. Kawamatawong T, Khiawwan S, Pornsuriyasak P. J Asthma Allergy. 2017 Feb 23;10:17-21. doi: 10.2147/JAA.S127580. eCollection 2017, Peak inspiratory flow rate measurement by using InCheck DIAL for the different inhaler devices in elderly with obstructive airway diseases.

8. Asthma care and factors affecting medication compliance: the patients point of view. International Journal for Quality in Health

9. Care 2001; Volume 13, Number 5: pp. 375-383

10. Buhl R. Volglelmeier C. Budesonie/Formeterol Mainatnence and Reliever Therapy. A new treatment approach for adult patients with asthma September 16,2007; http//:www.redorbit.com

11. Edward J. Sondik, Ph.D., Director, Jennifer H. Madans, Ph.D., Associate Director for Science, National Center for Health Statistics , National Surveillance of Asthma: United States, 20012010 , Series 3, Number 35. Available at https://www.cdc.gov/nchs/data/series/sr_03/sr03_ 035.pdf

12. https://www.sciencedirect.com/topics/nursingand-health professions/metered-dose-inhaler

13. Santus P, Giovanneli F, Marco FD et al. Budesonide/formeterol dry powder in asthma:an option for control as maintanence \& reliever therapy. Expert opin,Pharmacother 2010;11(2):257-267.

14. Jeanne E. Moorman, MS, ${ }^{1}$ Rose Anne Rudd, MSPH, ${ }^{1}$ Carol A. Johnson, MPH, ${ }^{1}$ Michael King, 
$\mathrm{PhD},{ }^{1}$ Patrick Minor, MSPH, ${ }^{1,2}$ Cathy Bailey, MS, ${ }^{1}$ Marissa R. Scalia, MPH, ${ }^{1,}{ }^{3}$ Lara J. Akinbami, $\mathrm{MD}^{4}{ }^{1}$ Division of Environmental Hazards and Health Effects, National Center for Environmental Health, CDC ${ }^{2}$ Lockheed Martin, Atlanta, Georgia ${ }^{3}$ Oak Ridge Institute for Science and Education, Oak Ridge, Tennessee ${ }^{4}$ Office of Analysis and Epidemiology, National Center for Health Statistics, CDC. National Surveillance for Asthma --- United States, 1980--2004 Available at

https://www.cdc.gov/mmwr/preview/mmwrhtml/ ss5608a1.htm

15. Martinez FD , Helms PJ Types of asthma and wheezing. The European Respiratory Journal. Supplement [01 Jul 1998, 27:3s-8s]. Available at http://europepmc.org/abstract/med/9699776

16. Mary Spitak Bilitski MSN, RN, Sally Wenzel MD; Cathy Vitari BSN, RN AE-C. American Thoracic Society: Patient Information Series. Available at https://www.thoracic.org/patients/patientresources/resources/asthma.pdf

17. Michael J Morris, MD, FACP, FCCP; Chief Editor: Zab Mosenifar, MD, FACP, FCCP Asthma Treatment \& Management,

18. Updated: Nov 20, 2017. Available at https://emedicine.medscape.com/article/296301treatment

19. Praveen Buddiga, MD Physician, Allergy, Asthma and Immunology, Baz Allergy, Asthma and Sinus Center, Use of Metered Dose Inhalers, Spacers, and Nebulizers. Available at https://emedicine.medscape.com/article/1413366overview\#a2

20. Thomas M Pavord I, Single inhaler maintanence and reliever therapy (SMART) in general practice asthma management. 